\title{
Protein HIRA
}

National Cancer Institute

\section{Source}

National Cancer Institute. Protein HIRA. NCI Thesaurus. Code C75509.

Protein HIRA (1017 aa, 112 kDa) is encoded by the human HIRA gene. This protein plays a role in both the localization of histones and chromatin assembly. 